\section{Summer Cover Crop and In-season Management System Affect Growth and Yield of Lettuce and Cantaloupe}

\author{
Guangyao Wang ${ }^{1}$ \\ Department of Botany and Plant Science, University of California, Riverside, \\ CA 92521
}

\section{Mathieu Ngouajio \\ Department of Horticulture, Michigan State University, East Lansing, MI 48824}

\author{
Milton E. McGiffen, Jr. ${ }^{2}$ \\ Department of Botany and Plant Sciences, University of California, \\ Riverside, Riverside, CA 92521-0124
}

\section{Chad M. Hutchinson}

Horticultural Sciences Department, University of Florida/IFAS, Hastings, FL 32145

\begin{abstract}
Additional index words. cowpea, sudangrass, integrated management, sustainable agriculture, organic vegetables
\end{abstract}

\begin{abstract}
The effect of summer cover crop and management system on subsequent fall romaine lettuce (Lactuca sativa $\mathrm{L}$.) and spring muskmelon (Cucumis melo $\mathrm{L}$.) growth and yield was evaluated in the Coachella Valley of California from 1999 to 2003. Cover crop treatments included: 1) cowpea [Vigna unguiculata (L.) Walp.] incorporated into the soil in the fall (CPI), 2) cowpea used as mulch in the fall (CPM), 3) sudangrass [Sorghum bicolor (L) Moench] incorporated into the soil in the fall (SGI), and 4) a bare ground control (BG). Management system treatments included: 1) conventional system (CON), 2) integrated crop management (ICM), and 3) organic system (ORG). Cowpea cover crop, either incorporated or used as surface mulch, increased lettuce growth and yield by increasing biomass allocation to lettuce leaf and leaf area growth. Cowpea mulch decreased muskmelon leaf and biomass growth and reduced muskmelon yield. Sudangrass produced more biomass than cowpea and reduced lettuce growth and yield. However, in the following spring, the SGI treatment had the highest muskmelon yield. Lettuce growth was significantly affected by management system, while muskmelon growth at the early stage was unaffected. The organic system reduced both lettuce and muskmelon yield compared with CON and ICM management systems.
\end{abstract}

The intensive vegetable production in the low desert valleys of southern California has traditionally relied on high inputs of pesticides and synthetic fertilizers. However, recent concerns about increased regulatory pressure to reduce nutrient input from agricultural fields to the nearby Salton Sea and decreased investment return have encouraged

\footnotetext{
Received for publication 9 Jan. 2008. Accepted for publication 10 Mar. 2008.

This research was partially supported by USDA's Western Region Sustainable Agriculture Research and Education program (WRSARE).

We thank Edmund Ogbuchiekwe, Vince Samons, and Lynn Morrison for technical help. We also thank Oli Bachie and Yusheng Zheng for their reviews of an earlier version of the manuscript.

${ }^{1}$ Current address: Department of Plant Sciences, University of Arizona, Maricopa Agricultural Center, 37860 W. Smith-Enke Road, Maricopa, AZ 85239 .

${ }^{2}$ To whom reprint requests should be addressed; e-mailmilt@ucr.edu
}

growers to adopt more sustainable production techniques such as crop rotation and the use of cover crops (Hartwig and Ammon, 2002).

Cover cropping may provide nitrogen for cash crops, add organic matter to soil, and improve the physical properties of soil (Aguiar et al., 2001; Creamer and Baldwin, 2000; Hartwig and Ammon, 2002). At the same time, planting cover crops could help suppress pest populations and reduce soil erosion, nutrient leaching, and contamination of surface and groundwater (Hartwig and Ammon, 2002; Hutchinson and McGiffen, 2000). However, cover crops could also reduce the subsequent crop yield (Al-Khatib et al., 1997; Scott and Knudsen, 1999). Although the practice of cover cropping is highly recommended in sustainable production, cover crops and crop management practices have to be carefully selected and investigated to maximize these benefits.

The common vegetable crop rotation in the low desert provides a niche in the cropping cycle that is ideal for a warm season cover crop. Lettuce is planted in the fall
(September to October) followed by spring muskmelon in February to March. After muskmelon harvest in June and July, there is not enough time to grow a third cash crop before the next lettuce season in the fall. In addition, excessive summer temperatures preclude the production of many vegetables in the area (Hutchinson and McGiffen, 2000). Production fields are traditionally fallowed during the hot summer months, creating a gap in the production season of 2 to 3 months to integrate cover crops into the vegetable production system.

Summer cover crops that fit into current desert production practices have to be heattolerant and capable of producing adequate biomass in a relatively short cycle (Aguiar et al., 2001). Cowpea and sudangrass are adapted to tropical conditions and tolerate high temperatures (Creamer and Baldwin, 2000). Cowpea is a leguminous cover crop used in many parts of the southern and western United States (Ehlers et al., 2002; Ehlers and Hall, 1997; Hall and Frate, 1996). Sudangrass is also a common warm season forage crop that forms a dense canopy that effectively shades out weeds. Both cowpea and sudangrass have been shown to suppress weeds and other pests when rotating with cash crops and to recycle excess nitrogen in the soil (Danso et al., 1991; Hutchinson and McGiffen, 2000; Roberts et al., 2005; Wang et al., 2006, 2008).

The objective of this work was to evaluate cowpea and sudangrass as potential cover crops for improvement of growth and yield in a lettuce-muskmelon rotation system in the low desert of southeastern California under three management systems, which included conventional, integrated crop management (ICM), and organic.

\section{Materials and Methods}

Site description. Field experiments were conducted from 1999 to 2003 at the University of California Coachella Valley Agricultural Research Station in Thermal, CA. The Coachella Valley is located in the lower Colorado River desert in Southern California. Field experiments were conducted on a Coachella sandy loam (coarse-silty, mixed, calcareous, hyperthermic typic torrifluvents) with $64 \%$ sand, $33 \%$ silt, less than $1 \%$ organic matter, and a $\mathrm{pH}$ of 8.3 . Mean daily temperature varies from 29 to $37{ }^{\circ} \mathrm{C}$ during the cover crop growing season, 11 to $23{ }^{\circ} \mathrm{C}$ during the lettuce growing season, and 13 to $34{ }^{\circ} \mathrm{C}$ during the muskmelon growing season.

Experimental design and field practices. The experimental plot area was fallow before seeding cowpea (var. Iron Clay) and sudangrass (var. Piper) cover crops in the summer of 1999. Cover crops were grown in the summer (from July to September) followed by lettuce in the fall (from October to December) and muskmelon in the spring (from February to June) from 1999 to 2003. The experiment was a split-plot design with four replications. The main plot factor was summer cover crop type and the subplot 
factor was management system. Cover crop treatments included: 1) cowpea incorporated into the soil in the fall (CPI), 2) summer cowpea used as surface mulch in the fall (CPM), 3) summer sudangrass incorporated into the soil in the fall (SGI), and 4) a summer bare ground dry fallow (BG). Summer bare ground dry fallow is the standard practice used by vegetable growers in the Coachella Valley (Hutchinson and McGiffen, 2000). Management systems included: 1) conventional (CON), 2) ICM, and 3) organic (ORG).

Each main plot was $18 \mathrm{~m}$ long and $9 \mathrm{~m}$ wide with six $1.5-\mathrm{m}$ beds. Main plots were further subdivided into three subplots of equal size each with six beds. The three subplots were then managed as the $\mathrm{CON}$, ICM, and ORG treatments. During the 5 years, all treatments (cover crop and management system) were kept in the same location using permanent marks.

Bare ground, sudangrass, or cowpea cover crop treatments were established in July of each year. Both sudangrass and cowpea cover crop were seeded as two double rows on each bed using a push planter at a rate of 50 and 60 $\mathrm{kg} \cdot \mathrm{ha}^{-1}$, respectively. Cover crops were dripirrigated and hand weeding was conducted 2 to 3 weeks after germination. Two months after planting, cover crops were incorporated and the beds reshaped (except in the cowpea mulch plots) before lettuce planting.

Synthetic fertilizer $(15 \mathrm{~N}-15 \mathrm{P}-15 \mathrm{~K})$ was used in the CON and ICM systems at a rate of $1130 \mathrm{~kg} \cdot \mathrm{ha}^{-1}$ and an organic fertilizer consisting of 50:50 composted yard waste and chicken manure $(\mathrm{N}=1.7 \%, \mathrm{P}=2.2 \%, \mathrm{~K}$ $=1.43 \%$ ) was used in the ORG system at a rate of $5 \mathrm{t} \cdot \mathrm{ha}^{-1} 2$ weeks before the lettuce crop and 4 weeks before the muskmelon crop. After application, beds were reshaped for transplanting, except CPM plots. For insect control, a formulation of Bacillus thuringiensis subsp. aizawai (XenTari, Valent BioSciences Corp., Libertyville, IL) was used in the ORG plots. In the CON and ICM plots, bifenthrin (Capture, FMC Agricultural Products, Philadelphia, PA) was used on lettuce and imidacloprid (Admire, Bayer CropSciences, RTP, NC) and bifenthrin on muskmelon for insect control. In the ORG and ICM plots, insecticide applications were initiated only when a threshold of two insects per 10 plants was reached. In the CON system, however, there was a preestablished schedule of four applications. In all treatments, weeds were controlled manually. The main difference between the CON and the ICM system was the reduced number of insecticide applications in the ICM system.

'Shining Star' romaine lettuce seedlings (Head Start Nursery, Gilroy, CA) were transplanted as double rows on $1.5-\mathrm{m}$ wide beds to a final density of 45,000 plant/ha on 19 Oct. 1999, 17 Oct. 2000, 11 Oct. 2001, 14 Oct. 2002, and 12 Oct. 2003. The field was irrigated by sprinklers during the first $3 \mathrm{~d}$ after transplanting and then drip-irrigated thereafter. Lettuce was harvested on 13 Dec. 1999,
20 Dec. 2000, 28 Nov. 2001, 6 Dec. 2002, and 10 Dec. 2003. Lettuce heads harvested from the four middle beds $\left(36 \mathrm{~m}^{2}\right)$ were separated into marketable and nonmarketable yield according to U.S. Department of Agriculture (USDA) standards (USDA, 2007). Marketable lettuce consists of plants that were well-developed, well-trimmed, and free from damages. Head number and total weight of marketable yield were recorded.

After lettuce harvest, crop residue was incorporated into the soil and the beds reshaped, except for the cowpea mulch plots that were maintained as no-till for the lettuce and muskmelon seasons. 'Magellan' muskmelon (Head Start Nursery, Gilroy, CA) was grown after lettuce in the rotation until the spring of 2004. Muskmelon was transplanted on 22 Mar. 2000, 16 Mar. 2001, 28 Mar. 2002, and 18 Feb. 2003 and harvested on 8 June 2000, 4 June 2001, 24 June 2002, and 20 June 2003. A second harvest was conducted 1 to 2 weeks after the first harvest. Muskmelon fruit were separated into marketable and nonmarketable yields according to USDA standards (USDA, 2007). Marketable fruits consist of muskmelons that are mature but not overripe, well-formed and well-netted, and free from damages. Crop residue was incorporated in all plots in 1 week after muskmelon harvest and beds reshaped with the same spacing as with the lettuce and muskmelon crops in preparation for the summer cover crop.

Before cover crop disking, an area of 1.5 $\mathrm{m}^{2}$ (1-m bed) was randomly chosen in each plot for biomass evaluation on 28 Sept. 1999 , 5 Sept. 2000, 26 Sept. 2001, 26 Sept. 2002, and 15 Sept. 2003. Plants within the area were cut at the soil surface and dried at $70{ }^{\circ} \mathrm{C}$ with ventilation until a constant weight was reached. Lettuce and muskmelon plants were sampled for growth analysis every 2 weeks for a total of five times and four times each year, respectively, from 1999 to 2001 growing seasons. At transplanting, 100 representative lettuce or muskmelon seedlings were sampled. During the next two samplings, 10 plants were cut at the soil surface. As a result of increased plant size, five plants were sampled on each of the remaining sampling dates. Both aboveground plant weight and leaf weight of lettuce or muskmelon were measured. Leaf area of each sample was also measured using a LI-3100 (Li-COR Biosciences, Lincoln, NE) optical leaf area meter.

Statistical analysis. Crop yield data were analyzed by analysis of variance and the means separated using Fisher's protected least protected difference at a probability level of 0.05. Data were combined when there were not significant year-by-treatment interactions. Year-by-treatment interactions of crop growth data were tested by analysis of covariance (McGiffen et al., 1997). Because interaction of cover crop and management system was not significant, results were presented as means for main plot and subplot treatments.
Exponential growth curves were fitted for shoot biomass, leaf area, or leaf weight samples as the dependent variable and with growing degree days (GDD) as the independent variable:

$$
\begin{aligned}
\mathrm{W}(\mathrm{GDD}) & =a_{w} \exp \left(b_{w} \mathrm{GDD}\right) \\
\mathrm{LA}(\mathrm{GDD}) & =a_{l a} \exp \left(b_{l a} \mathrm{GDD}\right) \\
\mathrm{LW}(\mathrm{GDD}) & =a_{l w} \exp \left(b_{l w} \mathrm{GDD}\right)
\end{aligned}
$$

where W(GDD), LA(GDD), and LW(GDD) are lettuce or muskmelon shoot biomass, leaf area, and leaf weight, respectively, over GDD. GDD was calculated using the single sine method (Zalom et al., 1983) with a base temperature of $3.5{ }^{\circ} \mathrm{C}$ for lettuce (Scaife et al., 1987) and $10^{\circ} \mathrm{C}$ for muskmelon (Baker and Reddy, 2001). Parameters $a_{w}, a_{l a}$, and $a_{l w}$ are initial value of shoot biomass, leaf area, and leaf biomass, respectively, when lettuce or muskmelon was transplanted. Parameters $b_{w}, b_{l a}$, and $b_{l w}$ are relative growth rate (RGR) of shoot biomass, leaf area, and leaf biomass, respectively. Parameters $b_{w}, b_{l a}$, and $b_{l w}$ of different cover crops and management systems were compared using the generalized linear model method in Wang et al. (2004).

Unit leaf ratio (ULR), leaf area ratio (LAR), specific leaf area (SLA), and leaf weight ratio (LWR) over GDD are obtained by functional growth analysis using parameters from Eqs. [1] to [3] (Chiariello et al., 1991):

$$
\begin{aligned}
\mathrm{ULR}(\mathrm{GDD}) & =\frac{1}{\mathrm{LA}(\mathrm{GDD})} \frac{\mathrm{d}(\mathrm{W}(\mathrm{GDD}))}{\mathrm{d}(\mathrm{GDD})} \\
& =\frac{a_{w} b_{w}}{a_{l a}} \exp \left[\left(b_{w}-b_{l a}\right) \mathrm{GDD}\right]
\end{aligned}
$$

$$
\begin{aligned}
\operatorname{LAR}(\mathrm{GDD}) & =\frac{\mathrm{LA}(\mathrm{GDD})}{\mathrm{W}(\mathrm{GDD})} \\
& =\frac{a_{l a}}{a_{w}} \exp \left[\left(b_{l a}-b_{w}\right) \mathrm{GDD}\right]
\end{aligned}
$$

$$
\begin{aligned}
\mathrm{SLA}(\mathrm{GDD}) & =\frac{\mathrm{LA}(\mathrm{GDD})}{\mathrm{LW}(\mathrm{GDD})} \\
& =\frac{a_{l a}}{a_{l w}} \exp \left[\left(b_{l a}-b_{l w}\right) \mathrm{GDD}\right]
\end{aligned}
$$

$$
\begin{aligned}
\mathrm{LWR}(\mathrm{GDD}) & =\frac{\mathrm{LW}(\mathrm{GDD})}{\mathrm{W}(\mathrm{GDD})} \\
& =\frac{a_{l w}}{a_{w}} \exp \left[\left(b_{l w}-b_{w}\right) \mathrm{GDD}\right]
\end{aligned}
$$

\section{Results}

Cover crop biomass. Because there were no year-by-treatment interactions, the averages of cover crop biomass from 1999 to 2003 are presented. The average cowpea biomass in the CPI and CPM treatments was 2.6 and $2.1 \mathrm{t} \cdot \mathrm{ha}^{-1}$, respectively (Fig. 1). Average biomass of sudangrass was 5.4 $\mathrm{t} \cdot \mathrm{ha}^{-1}$. Management system did not affect biomass production of cover crops. 


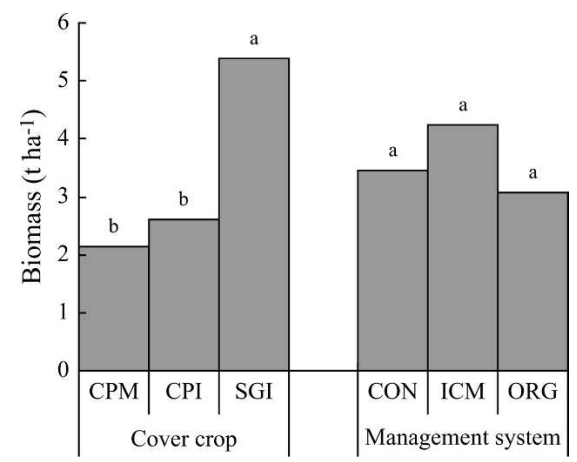

Fig. 1. Cover crop biomass in the summer immediately preceding lettuce. All cover crops were planted in the summer followed by lettuce in the fall from 1999 to 2003 . Cover crop treatments include cowpea incorporated into the soil (CPI), cowpea used as surface mulch (CPM), sudangrass incorporated into the soil (SGI), and a bare ground control (BG). Management system treatments include conventional $(\mathrm{CON})$, integrated crop management (ICM), and organic (ORG). The biomass data from 5 years were combined for analysis. Within each cover crop or management system, treatments followed by the same letter are not significantly different at $P=0.05$.

Lettuce growth and development. Relative growth rate was higher for lettuce plants in the CPI and CPM treatments compared with the SGI and BG treatments (Table 1). Compared with the BG treatment, both CPI and CPM increased lettuce RGR by $6 \%$. The CPI and CPM treatments also increased relative leaf area growth rate and relative leaf weight growth rate compared with the SGI and $\mathrm{BG}$ treatments. Lettuce in the $\mathrm{CON}$, ICM, and ORG systems had smaller RGR, relative leaf area growth rate, and relative leaf weight growth rate (Table 1). similar ULR, LAR, and SLA, indicating that cover crop treatment did not affect the lettuce biomass produced per unit leaf area, leaf area per unit shoot biomass, and leaf area per unit leaf biomass (Fig. 2). Plants in the CPI

Table 1. Growth parameters of lettuce affected by cover crops and management systems. ${ }^{2}$

\begin{tabular}{|c|c|c|c|c|}
\hline \multirow[b]{2}{*}{ Factor } & \multirow[b]{2}{*}{ Level } & $\begin{array}{l}\text { Relative growth } \\
\text { rate }\end{array}$ & $\begin{array}{l}\text { Relative leaf area } \\
\text { growth rate }\end{array}$ & $\begin{array}{l}\text { Relative leaf wt } \\
\text { growth rate }\end{array}$ \\
\hline & & \multicolumn{3}{|c|}{ 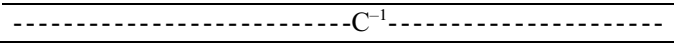 } \\
\hline \multirow{4}{*}{ Cover crop } & Initial value $^{\mathrm{y}}$ & 0.413 & 0.0158 & 0.348 \\
\hline & CPI & $0.00671 \mathrm{a}^{\mathrm{x}}$ & $0.00569 \mathrm{a}$ & $0.00673 \mathrm{a}$ \\
\hline & CPM & $0.00670 \mathrm{a}$ & $0.00575 \mathrm{a}$ & $0.00672 \mathrm{a}$ \\
\hline & SGI & $0.00614 \mathrm{~b}$ & $0.00503 \mathrm{~b}$ & $0.00615 \mathrm{~b}$ \\
\hline \multirow{5}{*}{ Management system } & BG & $0.00634 \mathrm{~b}$ & $0.00526 \mathrm{~b}$ & $0.00636 \mathrm{~b}$ \\
\hline & Initial value & 0.413 & 0.0158 & 0.348 \\
\hline & $\mathrm{CON}$ & $0.00655 \mathrm{a}$ & $0.00555 \mathrm{a}$ & $0.00658 \mathrm{a}$ \\
\hline & ICM & $0.00657 \mathrm{a}$ & $0.00557 \mathrm{a}$ & $0.00660 \mathrm{a}$ \\
\hline & ORG & $0.00628 \mathrm{~b}$ & $0.00518 \mathrm{~b}$ & $0.00630 \mathrm{~b}$ \\
\hline
\end{tabular}

${ }^{\mathrm{z}} \mathrm{All}$ cover crops were planted in the summer followed by lettuce in the fall from 1999 to 2003 . Cover crop treatments include cowpea incorporated into the soil (CPI), cowpea used as surface mulch (CPM), sudangrass incorporated into the soil (SGI), and a bare ground control (BG). Management system treatments include conventional (CON), integrated crop management (ICM), and organic (ORG). The growth data were measured every 2 weeks after lettuce transplanting until harvest from 1999 to 2001 and combined for analysis.

${ }^{\mathrm{y}}$ Exponential growth curves were fitted into data from different treatments within cover crop or management system using a common initial value because lettuce plants were the same at transplanting. ${ }^{\mathrm{x}}$ Within each cover crop or management system, treatments followed by the same letter are not significantly different at $P=0.05$.
Lettuce in all cover crop treatments had

treatment had the highest lettuce LWR, whereas the SGI treatment the lowest, indilettuce plants in the SGI treatmen leaves.

Management system did not affect lettuce ULR and SLA, but LAR and LWR were in the ORG system (Fig. 3). This system had lower leaf biomass and leaf area per unit shoot biomass as well as lower leaf ea per unit leaf biomass.

Lettuce yield. Lettuce yield data are presented separately for each year because there was significant year-by-treatment interaction
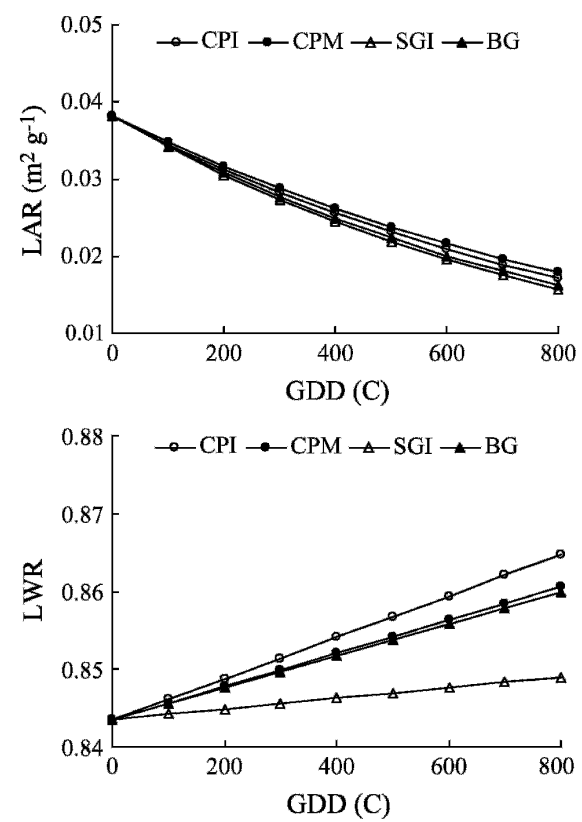

Fig. 2. Growth parameters of lettuce affected by cover crops. All cover crops were planted in the summer cowpea used as surface mulch (CPM), sudangrass incorporated into the soil (SGI), and a bare ground sample as dependent variable taken over the 1999, 2000, and 2001 growing seasons with growing

$(P<0.05)$. The CPI had the highest marketable weight and largest head number in the 1999 and 2000 growing seasons but equivalent yield to the BG treatment in 2001 to 2003 (Table 2). Lettuce in the CPM treatment produced higher marketable weight, head number, and head size compared with the BG treatment in the 2000 growing season but equivalent weight in the other four growing seasons. The SGI treatment had the lowest weight, head number, and head size in the 1999 growing season and lowest marketable weight in the 2002 growing season. There was no significant difference among cover crop treatments in 2003.

Compared with the ORG system, the CON and ICM systems had higher lettuce marketable weight in 1999 and 2001 and an equivalent marketable weight in 2000 (Table 2 ). However, the ORG system had higher or equivalent weight than the $\mathrm{CON}$ and ICM systems in 2002 and 2003. Lettuce head number in the ORG system was lower or equivalent in the first three growing seasons but higher in the last two growing seasons compared with the CON and ICM systems. The ORG system generally produced smaller head size compared with the CON system 4 of 5 years.

Muskmelon growth and development. Muskmelon plants in the CPM treatment had lower RGR, relative leaf area growth rate, and relative leaf weight growth rate than the CPI, SGI, and BG treatments (Table 3). Compared with the BG treatment, the CPM treatment reduced muskmelon RGR, relative leaf area growth rate, and relative leaf weight growth rate in the early growth stage by 

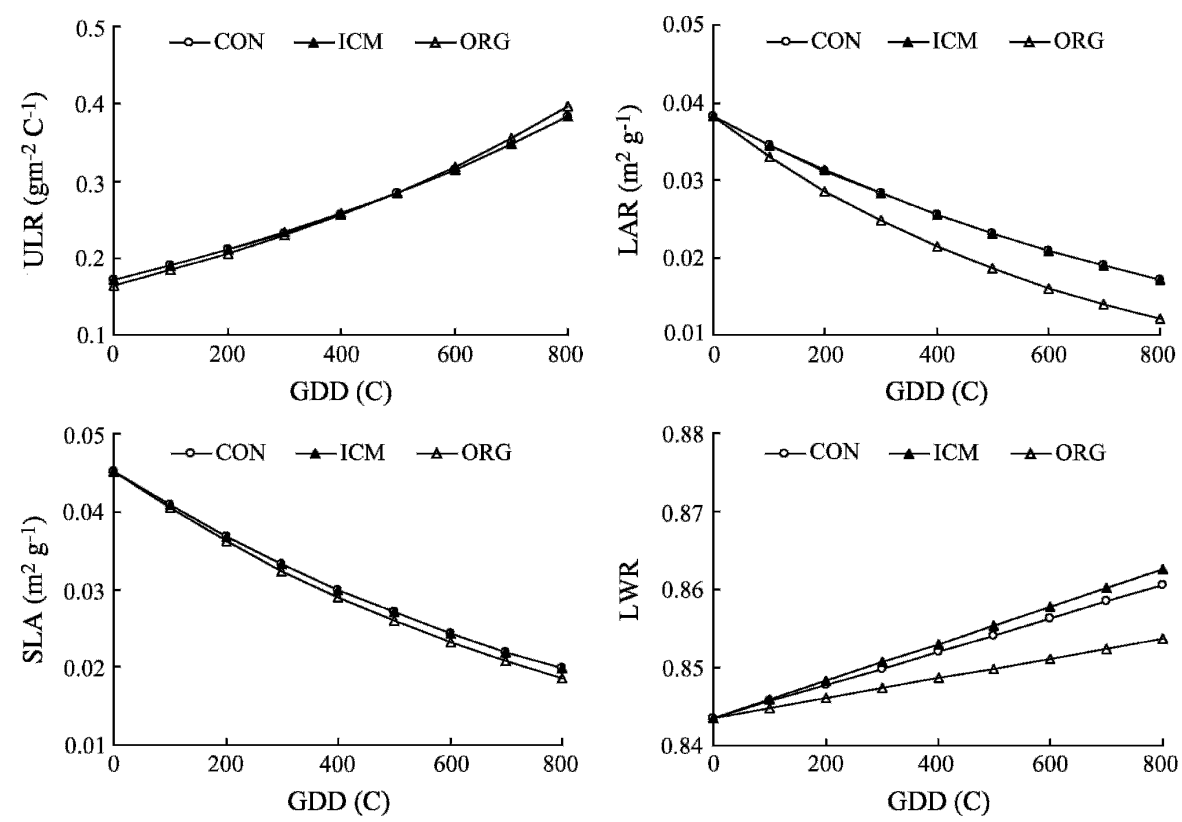

Fig. 3. Growth parameters of lettuce affected by management systems. All cover crops were planted in the summer followed by lettuce in the fall. Management system treatments include conventional (CON), integrated crop management (ICM), and organic (ORG). Exponential growth curves were fitted into lettuce shoot biomass, leaf area, or leaf weight sample as the dependent variable with growing degree days (GDD) as the independent variable. Relative growth rate (RGR), unit leaf ratio (ULR), leaf area ratio (LAR), specific leaf area (SLA), and leaf weight ratio (LWR) were derived using functional growth analysis. The data from the 3 years were combined for analysis.

$6.2 \%, 7.1 \%$, and $7.0 \%$, respectively. This may have been the result of significant crop residues left on the ground in the CPM plots at muskmelon planting. Management systems did not affect muskmelon leaf area and biomass growth.

Muskmelon plants in all cover crop treatments had similar ULR, LAR, and SLA early in the growing season, indicating that the cover crop treatment did not affect the efficiency of new growth produced by leaves and leaf area per unit biomass or per unit leaf biomass (data not shown). Plants in the CPM treatment had lowest LWR among the treatments, indicating that muskmelon plants in the CPM treatment invested more biomass into stem instead of leaves and resulted in lower RGR, relative leaf area growth, and relative leaf weight growth. The ORG management system did not affect ULR, LAR,
SLA, and LWR compared with the CON and ICM systems (data not shown).

Muskmelon yield. Because there was no significant year-by-treatment interaction for muskmelon yield, the yield data were pooled for analysis. After cover crop in the previous summer and lettuce in the previous fall, the SGI and CPI treatments had higher muskmelon marketable fruit weight than the $\mathrm{BG}$ and CPM treatments resulting from higher marketable fruit number (Table 4). Compared with the BG treatment, the SGI and CPI treatments increased muskmelon weight by $18.2 \%$ and $13.1 \%$, respectively. Cover crop treatments did not affect muskmelon fruit size.

Although similar early growth was observed in all management system treatments, the CON and ICM treatments produced higher marketable fruit weight and fruit number compared with the ORG system. ORG treatment reduced muskmelon fruit weight by $14.7 \%$ compared with the CON system. Management system did not affect muskmelon fruit size.

\section{Discussion}

In a North Carolina study using the same cultivars, the $\mathrm{C}: \mathrm{N}$ ratio of cowpea (21) was less than half that of sudangrass (53; Creamer and Baldwin, 2000). The nitrogen-fixing property of cowpea makes it a promising summer cover crop for intensive vegetable production in the low desert. Our results showed that cowpea cover crop incorporated into the soil in the fall increased the yield of both fall lettuce ( 2 of 5 years) and spring muskmelon. Using cowpea as a surface mulch has been shown to increase soil fertility and reduce pest problems in the field in the low desert area (Hutchinson and McGiffen, 2000; Roberts et al., 2005). Cover crop mulch has also been shown to reduce emergence of annul weed. However, perennial weed species often increase as a result of reduced tillage when cover crop mulch is used (Buhler, 1995; Hartwig and Ammon, 2002). In our study, using cowpea as a surface mulch resulted in increased lettuce yield but decreased muskmelon yield. Because early muskmelon growth was unaffected, reduced muskmelon yield was probably the result of late-season weed competition, when the spreading characteristics of the muskmelon canopy interfered with hand weeding. Increased perennial weed species would require increased herbicide input in the nonorganic system and could be a serious weed problem in the organic system.

Research has shown that high $\mathrm{C}: \mathrm{N}$ ratio and biomass production of sudangrass may immobilize nitrogen and reduce nitrogen availability to the next cash crop (Creamer and Baldwin, 2000). The lower nitrogen in the soil and allelopathic effects of sudangrass could have reduced lettuce leaf area and biomass growth rates, which reduced lettuce marketable weight and head size in three of the five growing seasons compared with the CPI treatment (Weston et al., 1989). Another disadvantage for sudangrass was that the large amount of biomass interfered with

Table 2. The effect of cover crop and management system on lettuce marketable yield in the five growing seasons. ${ }^{\mathrm{z}}$

\begin{tabular}{|c|c|c|c|c|c|c|c|c|c|c|c|c|c|c|c|c|}
\hline \multirow[b]{3}{*}{ Factor } & \multirow[b]{3}{*}{ Level } & \multicolumn{5}{|c|}{ Lettuce wt } & \multicolumn{5}{|c|}{ Lettuce head number } & \multicolumn{5}{|c|}{ Lettuce head size } \\
\hline & & 1999 & 2000 & 2001 & 2002 & 2003 & 1999 & 2000 & 2001 & 2002 & 2003 & 1999 & 2000 & 2001 & 2002 & 2003 \\
\hline & & \multicolumn{5}{|c|}{$\mathrm{t} \cdot \mathrm{ha} \mathrm{a}^{-1}$} & \multicolumn{5}{|c|}{$\longrightarrow 1000 \mathrm{ha}^{-1}$} & \multicolumn{5}{|c|}{$-\mathrm{g}$} \\
\hline \multirow[t]{4}{*}{ Cover crop } & CPI & $9.8 \mathrm{a}^{\mathrm{y}}$ & $10.2 \mathrm{a}$ & $8.0 \mathrm{a}$ & $12.5 \mathrm{a}$ & $8.5 \mathrm{a}$ & $31.1 \mathrm{a}$ & $35.2 \mathrm{a}$ & $43.5 \mathrm{ab}$ & $52.3 \mathrm{a}$ & $53.2 \mathrm{a}$ & $316 a$ & $292 \mathrm{~b}$ & $182 \mathrm{a}$ & $235 \mathrm{ab}$ & $160 \mathrm{a}$ \\
\hline & CPM & $7.8 \mathrm{~b}$ & $8.8 \mathrm{~b}$ & $8.0 \mathrm{a}$ & $12.8 \mathrm{a}$ & $8.9 \mathrm{a}$ & $24.5 \mathrm{~b}$ & $27.3 \mathrm{~b}$ & $42.1 \mathrm{~b}$ & $50.2 \mathrm{a}$ & $54.7 \mathrm{a}$ & $314 \mathrm{a}$ & $326 \mathrm{a}$ & $189 \mathrm{a}$ & $255 \mathrm{a}$ & $162 \mathrm{a}$ \\
\hline & SGI & $3.8 \mathrm{c}^{\mathrm{x}}$ & $7.7 \mathrm{~b}$ & $7.2 \mathrm{a}$ & $11.1 \mathrm{~b}$ & $8.7 \mathrm{a}$ & $13.0 \mathrm{c}$ & $27.3 \mathrm{~b}$ & $43.0 \mathrm{ab}$ & $51.6 \mathrm{a}$ & $53.7 \mathrm{a}$ & $273 \mathrm{~b}$ & $280 \mathrm{~b}$ & $167 \mathrm{a}$ & $216 \mathrm{~b}$ & $163 \mathrm{a}$ \\
\hline & BG & $8.1 \mathrm{~b}$ & $5.7 \mathrm{c}$ & $7.7 \mathrm{a}$ & $12.1 \mathrm{ab}$ & $8.0 \mathrm{a}$ & $24.8 \mathrm{~b}$ & $19.5 \mathrm{c}$ & $43.9 \mathrm{a}$ & $51.7 \mathrm{a}$ & $53.5 \mathrm{a}$ & $316 \mathrm{a}$ & $299 \mathrm{~b}$ & $176 \mathrm{a}$ & $234 \mathrm{ab}$ & $151 \mathrm{a}$ \\
\hline \multirow{3}{*}{$\begin{array}{l}\text { Management } \\
\text { system }\end{array}$} & $\mathrm{CON}$ & $9.0 \mathrm{a}$ & $8.2 \mathrm{a}$ & $7.9 \mathrm{a}$ & $11.6 \mathrm{~b}$ & $8.6 \mathrm{a}$ & $27.2 \mathrm{a}$ & $26.2 \mathrm{a}$ & $43.2 \mathrm{a}$ & $49.9 \mathrm{~b}$ & $50.7 \mathrm{~b}$ & $329 a$ & $317 \mathrm{a}$ & $183 \mathrm{a}$ & $232 \mathrm{a}$ & $170 \mathrm{a}$ \\
\hline & ICM & $8.0 \mathrm{a}$ & $8.5 \mathrm{a}$ & $9.1 \mathrm{a}$ & $11.4 \mathrm{~b}$ & $8.1 \mathrm{a}$ & $24.7 \mathrm{a}$ & $27.5 \mathrm{a}$ & $42.7 \mathrm{a}$ & $48.4 \mathrm{~b}$ & $50.8 \mathrm{~b}$ & $312 \mathrm{a}$ & $313 \mathrm{a}$ & $213 \mathrm{a}$ & $237 \mathrm{a}$ & $158 \mathrm{ab}$ \\
\hline & ORG & $5.1 \mathrm{~b}$ & $7.6 \mathrm{a}$ & $6.1 \mathrm{~b}$ & $13.1 \mathrm{a}$ & $8.9 \mathrm{a}$ & $18.2 \mathrm{~b}$ & $28.3 \mathrm{a}$ & $43.5 \mathrm{a}$ & $55.8 \mathrm{a}$ & $59.8 \mathrm{a}$ & $273 \mathrm{~b}$ & $269 \mathrm{~b}$ & $140 \mathrm{~b}$ & $234 \mathrm{a}$ & $149 \mathrm{~b}$ \\
\hline
\end{tabular}

${ }^{\mathrm{z}}$ All cover crops were planted in the summer followed by lettuce in the fall from 1999 to 2003. Cover crop treatments include cowpea incorporated into the soil (CPI), cowpea used as surface mulch (CPM), sudangrass incorporated into the soil (SGI), and a bare ground control (BG). The yield data were analyzed separately because significant year-by-treatment interactions.

${ }^{\mathrm{y}}$ Within each cover crop or management system, treatments within a column followed by the same letter are not significantly different at $P=0.05$.

${ }^{\mathrm{x}}$ The low lettuce yield was caused by short time between sudangrass incorporation and lettuce transplanting ( $22 \mathrm{~d}$ ) and many sudangrass volunteers during lettuce growth. After 1999, sudangrass was incorporated into the soil before seed setting and the time between sudangrass incorporation and lettuce transplanting was at least $30 \mathrm{~d}$. 
Table 3. Growth parameters of muskmelon affected by cover crops and management systems. ${ }^{2}$

\begin{tabular}{llccc}
\hline & & $\begin{array}{c}\text { Relative growth } \\
\text { rate }\end{array}$ & $\begin{array}{c}\text { Relative leaf area } \\
\text { growth rate }\end{array}$ & $\begin{array}{c}\text { Relative leaf wt } \\
\text { growth rate }\end{array}$ \\
\cline { 3 - 5 } Factor & \multicolumn{1}{c}{ Level } & 0.335 & 0.0055 & 0.238 \\
\hline \multirow{3}{*}{ Cover crop } & Initial value & $0.0098 \mathrm{a}$ & $0.0113 \mathrm{a}$ \\
& CPI & $0.0117 \mathrm{a}^{\mathrm{x}}$ & $0.0089 \mathrm{~b}$ & $0.0104 \mathrm{~b}$ \\
& CPM & $0.0108 \mathrm{~b}$ & $0.0098 \mathrm{a}$ & $0.0112 \mathrm{a}$ \\
& SGI & $0.0116 \mathrm{a}$ & $0.0096 \mathrm{a}$ & $0.0112 \mathrm{a}$ \\
& BG & $0.0116 \mathrm{a}$ & 0.0055 & 0.238 \\
Management & Initial value & 0.335 & $0.0094 \mathrm{a}$ & $0.0109 \mathrm{a}$ \\
system & CON & $0.0114 \mathrm{a}$ & $0.0096 \mathrm{a}$ & $0.0112 \mathrm{a}$ \\
& ICM & $0.0115 \mathrm{a}$ & $0.0095 \mathrm{a}$ & $0.0110 \mathrm{a}$ \\
\hline
\end{tabular}

${ }^{\mathrm{z}} \mathrm{All}$ cover crops were planted in the previous summer followed by lettuce in the previous fall and muskmelon in the spring of 2000, 2001, 2002, and 2003. Cover crop treatments include cowpea incorporated into the soil (CPI), cowpea used as surface mulch (CPM), sudangrass incorporated into the soil (SGI), and a bare ground control (BG). Management system treatments include conventional (CON), integrated crop management (ICM), and organic (ORG). The growth data were measured every 2 weeks after muskmelon transplanting for four times each year from 2000 to 2002 and combined for analysis. ${ }^{\mathrm{y}}$ Exponential growth curves were fitted into data from different treatments within cover crop or management system using a common initial value because muskmelon plants were same at transplanting. ${ }^{\mathrm{x}}$ Within each cover crop or management system, treatments following the same letter are not significantly different at $P=0.05$.

Table 4. The effect of cover crops and management systems on muskmelon marketable yield in the four growing seasons. ${ }^{\mathrm{z}}$

\begin{tabular}{lllcr}
\hline Factors & Levels & $\begin{array}{l}\text { Fruit wt } \\
\left(\mathrm{t} \cdot \mathrm{ha}^{-1}\right)\end{array}$ & $\begin{array}{c}\text { Fruit number } \\
\left(\times 1000 \mathrm{ha}^{-1}\right)\end{array}$ & \multicolumn{1}{c}{$\begin{array}{c}\text { Fruit size } \\
(\mathrm{G})\end{array}$} \\
\hline Cover crop & CPI & $24.0 \mathrm{a}^{\mathrm{y}}$ & $24.3 \mathrm{a}$ & $997.9 \mathrm{a}$ \\
& CPM & $21.0 \mathrm{~b}$ & $21.1 \mathrm{~b}$ & $1,008.8 \mathrm{a}$ \\
& SGI & $25.1 \mathrm{a}$ & $24.5 \mathrm{a}$ & $1,000.4 \mathrm{a}$ \\
\multirow{3}{*}{ Management system } & BG & $21.3 \mathrm{~b}$ & $21.5 \mathrm{~b}$ & $1,033.0 \mathrm{a}$ \\
& CON & $23.7 \mathrm{a}$ & $23.3 \mathrm{a}$ & $1,021.0 \mathrm{a}$ \\
& ICM & $24.7 \mathrm{a}$ & $24.7 \mathrm{a}$ & $1,011.8 \mathrm{a}$ \\
& ORG & $20.2 \mathrm{~b}$ & $20.5 \mathrm{~b}$ & $997.1 \mathrm{a}$ \\
\hline
\end{tabular}

${ }^{\mathrm{z}}$ All cover crops were planted in the previous summer followed by lettuce in the previous fall and muskmelon in the spring of 2000, 2001, 2002, and 2003. Cover crop treatments include cowpea incorporated into the soil (CPI), cowpea used as surface mulch (CPM), sudangrass incorporated into the soil (SGI), and a bare ground control (BG). Management system treatments include conventional (CON), integrated crop management (ICM), and organic (ORG). The yield data were combined because there were no significant year-by-treatment interactions.

${ }^{\mathrm{y}}$ Treatments within a column followed by the same letter are not significantly different at $P=0.05$.

lettuce transplanting, partially contributing to the lower lettuce marketable head number in two of the five growing seasons in the SGI treatment. However, sudangrass increased after muskmelon yield by $18.2 \%$, probably as a result of the long and steady availability of nitrogen in the soil from the decomposition of sudangrass residue (Myers et al., 1997).

Summer cover crops helped improve Coachella Valley fall lettuce and spring muskmelon growth and yield in this research. The integration of appropriate cover crops into the production system could improve the current vegetable rotations. Cowpea cover crops, either soil-incorporated or as a surface mulch, would fit in conventional, integrated, and organic production systems. A sudangrass cover crop should be carefully managed to avoid potential yield loss.

In this study, management system had a significant effect on the growth and yield of lettuce and muskmelon. Compared with the CON system, lettuce marketable weight and head number in the ORG system were lower or equivalent in the first 3 years but higher or equivalent in the fourth and fifth years. Results of this study are similar to results obtained by other researchers (Blackshaw,
2005; Liebhardt et al., 1989; MacRae et al., 1993). For example, Blackshaw (2005) showed that wheat yield with organic fertilizer (manure or compost) was lower during the first year of the experiment and then equivalent in the third and fourth year to broadcast and banded granular ammonium nitrate under weed-free conditions. These results indicate that soils under long-term conventional management may require more than 2 years reaching a new equilibrium under organic management (Delate, 2002; Drinkwater, 2002). Lettuce plants in the ORG system had slower leaf and biomass growth than in the CON system, resulting in smaller head size in 4 of 5 years.

Although muskmelon plants in the ORG system had growth rates comparable to the CON system at the early growth stage, muskmelon fruit weight and fruit number in the ORG system were smaller, indicating that muskmelon yield was reduced at the later stage in the ORG system. The lower muskmelon yield was probably the result of lateseason weed competition because there were considerable weeds left after the third weeding in the muskmelon crop as a result of spreading character of muskmelon canopy, and organic fertilizer may increase weed competitive ability with crops (Blackshaw, 2005; Menalled et al., 2004).

\section{Literature Cited}

Aguiar, J.L., W.A. Williams, W.L. Graves, M.E. McGiffen, Jr., J.V. Samons, J.D. Ehlers, and W.C. Matthews, Jr. 2001. Factor for estimating nitrogen contribution of cowpea as a cover crop. J. Agron. Crop Sci. 186:145-149.

Al-Khatib, K., C. Libbey, and R. Boydston. 1997. Weed suppression with Brassica green manure crops in green pea. Weed Sci. 45:439-445.

Baker, J.T. and V.R. Reddy. 2001. Temperature effects on phenological development and yield of muskmelon. Ann. Bot. (Lond.) 87:605613.

Blackshaw, R.E. 2005. Nitrogen fertilizer, manure, and compost effects on weed growth and competition with spring wheat. Agron. J. 97:1612-1621.

Buhler, D.D. 1995. Influence of tillage systems on weed population dynamics and management in corn and soybean in the central USA. Crop Sci. 35:1247-1258.

Chiariello, N.R., H.A. Mooney, and K. Williams. 1991. Growth, carbon allocation and cost of plant tissues, p. 327-334. In: Pearcy, R.W., J.R. Ehleringer, H.A. Mooney, and P.W. Rundel (eds.). Plant physiological ecology: Field methods and instrumentation. Chapman and Hall, New York, NY.

Creamer, N.G. and K.R. Baldwin. 2000. An evaluation of summer cover crops for use in vegetable production systems in North Carolina. HortScience 35:600-603.

Danso, S.K., C. Labandera, D. Pastorini, and S. Curbelo. 1991. Herbage yield and nitrogen fixation in a triple species mixed sward of white clover, lotus and fescue. Soil Bio. Biochem. 23:65-70.

Delate, K. 2002. Using an agroecological approach to farming systems research. HortTechnology $12: 345-354$

Drinkwater, L.E. 2002. Cropping systems research: Reconsidering agricultural experimental approaches. HortTechnology 12:355-361.

Ehlers, J.D., R.L. Fery, and A.E. Hall. 2002. Cowpea breeding in the USA: New varieties and improved germplasm, p. 62-77. In: Fatokun, C.A., S.A. Tarawali, B.B. Singh, P.M. Kormawa, and M. Tamo (eds.). Challenges and opportunities for enhancing sustainable cowpea production. International Institute of Tropical Agriculture, Ibadan, Nigeria.

Ehlers, J.D. and A.E. Hall. 1997. Cowpea [Vigna unguiculata (L.) Walp.]. Field Crops Res. 53:187-204

Hall, A. and C.A. Frate. 1996. Blackeye bean production in California. University of California DANR Publication 21518.

Hartwig, N.L. and H.U. Ammon. 2002. 50th anniversary-Invited article: Cover crop and living mulches. Weed Sci. 50:688-699.

Hutchinson, C.M. and M.E. McGiffen, Jr. 2000. Cowpea cover crop mulch for weed control in desert pepper production. HortScience 35:196198.

Liebhardt, W.C., R.W. Andrews, M.N. Culik, R.R. Harwood, R.R. Janke, J.K. Radke, and S.L. Rieger-Schwartz. 1989. Crop production during conversion from conventional to lowinput methods. Agron. J. 81:150-159.

MacRae, R.J., S.B. Hill, G.R. Mehuys, and J. Henning. 1993. Farm-scale agronomic and economic conversion from conventional to 
sustainable agriculture. Adv. Agron. 43:155198.

McGiffen, M.E., Jr., F. Forcella, M.J. Lindstrom, and D.C. Reicosky. 1997. Covariance of cropping systems and foxtail density as predictors of weed interference. Weed Sci. 45:388-396.

Menalled, F.D., M. Liebman, and D.D. Buhler. 2004. Impact of composted swine manure and tillage on common waterhemp (Amaranthus rudis) competition with soybean. Weed Sci. 52:605-613.

Myers, R.J.K., M. van Noordwijk, and P. Vityakon. 1997. Synchrony of nutrient release and plant demand: Plant litter quality, soil environment and farmer management options, p. 215-229. In: Cadisch, G. and K.E. Giller (eds.). Driven by nature: Plant litter quality and decomposition. CAB International, Wallingford, UK.

Roberts, P.A., W.C. Matthews, Jr., and J.D. Ehlers 2005. Root-knot nematode resistant cowpea cover crops in tomato production systems. Agron. J. 97:1626-1635.

Scaife, A., E.F. Cox, and G.E.L. Morris. 1987. The relationship between shoot weight, plant density and time during the propagation of four vegetable species. Ann. Bot. (Lond.) 59:325334.

Scott, J. and G. Knudsen. 1999. Soil amendment effects of rape (Brassica napus) residues on pea rhizosphere bacteria. Soil Biol. Biochem. 31:1435-1441.

U.S. Department of Agriculture. 2007. Quality standards: Fresh fruits and vegetables. 6 Nov. 2007. <http://www.ams.usda.gov/standards/ vegfm.htm>. U.S. Department of Agriculture, Washington, DC.

Wang, G., J.D. Ehlers, E.C.S. Marchi, and M.E. McGiffen. 2006. Competitive ability of cowpea (Vigna unguiculata) genotypes with different growth habit. Weed Sci. 54:775-782.
Wang, G., J.D. Ehlers, E.J. Ogbuchiekwe, S. Yang, and M.E. McGiffen, Jr. 2004. Competitiveness of erect, semi-erect, and prostrate cowpea (Vigna unguiculata) genotypes with sunflower (Helianthus annuus) and purslane (Portulaca oleracea). Weed Sci. 52:815-820.

Wang, G., M. Ngouajio, and D.D. Warncke. 2008. Nutrient cycling, weed suppression, and onion yield following brassica and sorghum sudangrass cover crops. HortTechnology 18 : 68-74.

Weston, L.A., R. Harmon, and S. Mueller. 1989. Allelopathic potential of sorghum-sudangrass hybrid (Sudex). J. Chem. Ecol. 15:1855-1865.

Zalom, F.G., P.B. Goodell, L.T. Wilson, W.W. Barnett, and W.J. Bentley. 1983. Degree-days: The calculation and use of heat units in pest management. University of California Division of Agriculture and Natural Resources Leaflet 21373. 